\title{
Research on Improving the Informatization Teaching Ability of Civil Engineering Teachers in BIM Environment
}

\author{
Huiqin Yang, Xiuyan Zhang, Jinfang Sun, Lixin Xu, Chengjie Luan
}

Binzhou Polytechnic, Binzhou 256603, China

317698397@qq.com

Keywords: Construction Industry; Informatization; Teachers' Ability; BIM; Assembly Construction

\begin{abstract}
With the rapid development of information technology, the degree of informatization in the construction industry has also been greatly improved. Particularly, the development of BIM technology and assembly construction technology as well as the development of green building leads to the upgrading of the construction industry. This requires teachers to master the information products of the new era to be qualified for the teaching work. Based on the principle of " post ability, teacher first ", this paper puts forward a spiral-upgrading teacher's ability upgrading plan to deal with the transformation and upgrading of construction industry. Teachers' ability is promoted through teacher training, enterprise training and building network learning platform.
\end{abstract}

In March 2016, the "two sessions" and the Fourth Session of the Twelfth National People's Congress were held. The meeting adopted the "13th Five-year" plan for economic and social development. The plan clearly puts forward that talent training in vocational education should be based on enhancing morality and respecting teacher education. We should carry out professional layout and industrial needs docking, curriculum content and professional standards docking, teaching process docking with production process, graduation certificate and vocational qualification certificate docking, vocational education and lifelong learning docking.

The establishment of BIM building information model is a revolution in the field of architecture and it will become a powerful tool for project management. The mastery of BIM technology can help us develop better in the construction industry. The construction of green building is the mission of every practitioner, and it is also the responsibility of the construction industry. On November 14, 2015, the Ministry of Housing and Construction issued the "Outline for the Modernization of the Construction Industry”. It is planned that by 2020, the percentage of prefabricated buildings will account for more than $20 \%$ of the newly-built buildings, and by 2025, prefabricated buildings will account for more than $50 \%$ of the new buildings. The birth of new technology in the construction industry has caused the upgrading of the construction industry and brought new opportunities and challenges for teachers of the construction industry. At the same time, it also puts forward new requirements for the professional teachers in the construction industry in the new knowledge and new skills. And requires teachers to grasp the information products in order to be competent for teaching. Since 2010, our research group has investigated the mastery of new knowledge and skills for professional teachers in higher vocational colleges. The investigation found that teachers know that the upgrading of the construction industry is not comprehensive and unsystematic, and their practice ability of the new technology is not very good. It is urgent to improve the ability of professional teachers of civil engineering in higher vocational colleges to form a systematic implementation plan.

\section{Construction ideas}

It is very important to carry out the national and provincial document spirit, which is related to the development of vocational education and the development of teachers. The demand for teaching is taken as a guide. The improvement of the quality of teachers' double quality, the training of all 
teachers and the construction and sharing of excellent courses in civil engineering are used as means. The construction of the double-quality teachers' team, the construction of the excellent courses and the development of the teaching and scientific research projects are the key points. The establishment and improvement of relevant policies, systems, and incentives are used as safeguards.

Under the new demand for the upgrading of the construction industry, in order to foster the precise docking of students' job abilities and business needs, teachers of higher vocational civil engineering majors need to clarify the direction of further studies and urgently need to acquire new knowledge, new skills and new ideas. Based on this, for the purpose of implementing the concept of "post ability, teacher first", teachers should be systematically trained in advance to improve the teaching ability of BIM technology and assembly-type construction technology. Higher vocational colleges and related construction enterprises jointly build the construction industry upgrading Education Alliance, and jointly create BIM technology and assembly building education platform to share theoretical knowledge. Enterprises provide practical platform for teachers to study and exercise. Through the school-enterprise coalition, the key technologies and difficulties that have emerged at the frontier of construction have been systematically compiled, compiled into volumes, and serviced by teachers. Based on this, the teachers' actual post ability has been effectively improved. The overall construction ideas are shown in Fig.1.

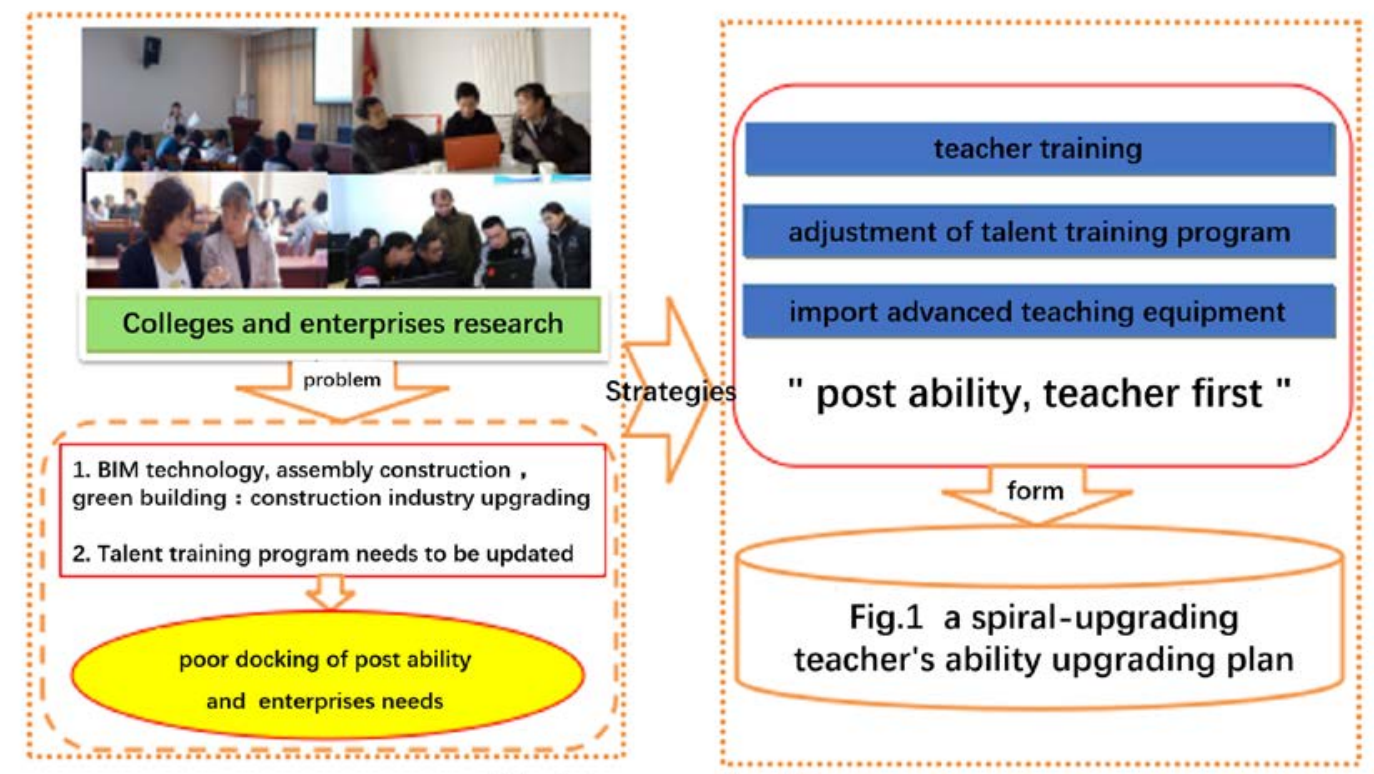

Fig.1 Construction ideas

\section{Teaching problems and methods to solve}

According to the requirements of the upgrading of construction industry, we have investigated the talent training programs, practical training conditions and teachers' knowledge of new knowledge and new skills in vocational schools nationwide. We have actively organized the Shandong Province engineering cost specialty teaching guidance program seminar. We have also participated in other professional teaching program seminars in Shandong Province, such as construction engineering, engineering survey, engineering supervision, etc. It summarizes and analyzes the teaching problems that need to be solved in the civil engineering majors in vocational colleges and proposes solutions to the problems.

\subsection{Mainly solved teaching problems}

\subsubsection{The direction of teachers' promotion is not clear}

Under the new demand for the upgrading of the construction industry, the professional teachers of civil engineering are not clear in the direction of further study, which leads to the poor docking of 
the students' post ability and the needs of the enterprises. Teachers urgently need to master new knowledge and new skills to adapt to the transformation and upgrading of the construction industry.

\subsubsection{The self-improvement effect of teachers is not obvious}

The various promotion methods adopted by the teachers themselves are not well-targeted, and the promotion effect is not obvious. The new knowledge and new skills brought by the upgrading of the construction industry cannot be grasped.

\subsubsection{Teachers' lack of informatization teaching ability}

Under the new demand for the upgrading of the construction industry, informatization technology has become an unavoidable teaching tool. However, if teachers still stay in traditional teaching methods and methods, they can't adapt to the informatization teaching needs of BIM technology, assembly construction and green building. In addition, it is difficult for teachers to be qualified for the three-dimensional development of teaching resources, nor can they satisfy the requirements of the current "Internet+" online and offline teaching models.

\subsection{Solution}

\subsubsection{Formulate a " spiral-upgrading" teacher's ability improvement plan}

Keeping pace with the upgrading of the construction industry, aiming at the impact of new knowledge and new skills brought about by each industrial upgrading, the objectives, methods, contents and evaluations of teacher training are formulated to form a "spiral-upgrading" teacher ability improvement program. It effectively solves the problems arising from the lack of teachers' knowledge and the lack of information teaching ability caused by the upgrading of the construction industry in the background of vocational education.

\subsubsection{Schools and enterprises jointly formulate talent training programs}

On the basis of the university-enterprise cooperation, the research of professional teachers' competence in vocational colleges is carried out. The talent training program adapted to the upgrading of the construction industry was formulated. We revise the talent training program at least once a year and integrate the upgrade content of the construction industry into the newly updated talent training program. The curriculum standards and teachers' teaching content have been updated to ensure that the students' content is in line with the new standards of the industry.

\subsubsection{Teachers go to enterprises to study and exercise}

Excellent teachers should be trained in enterprises to keep pace with the upgrading of construction industry. We should get first-line information, knowledge and skills in the industry so as to keep pace with the times, and truly achieve "new knowledge and skills, teacher first".

\subsubsection{Teacher training}

In order to allow teachers to acquire new knowledge and new skills, professional teachers should be organized to receive provincial or national teacher training in BIM technology, assembly construction and green building to ensure the advancement of teachers' ability.

\subsubsection{Build the industry upgrading platform for the construction industry through the}

\section{"Internet"}

In order to facilitate teachers' timely understanding of industry upgrading information, senior industrial personnel and outstanding backbone teachers take the lead in building "industrial upgrading network platform for construction industry", which can provide updated information, lectures, video teaching in time. The platform is open and constantly updated. With the expansion of new theories and skills of the construction industry, the learners will learn "fresh nutrition" in a 
timely manner. Through this platform, learners can get to know the talent training objectives and capability requirements of the industry and professional positions timely. They can also learn about the development of industry companies and can understand the development and application of new designs, new processes, new materials and new products.

\subsubsection{Capture new industry trends through "teaching and scientific research projects"}

Teaching and scientific research projects are carried out, under the informatization background of BIM technology, assembly construction and green building. For the purpose of meeting the new needs of the upgrading of the construction industry, the new trends of industry development are captured and related papers are written, through the teaching and scientific research.

\section{Achievements and effectiveness}

Under the new demand of building industry upgrading such as BIM technology, assembly construction and green intelligent building, the post ability of trained talents in traditional talent training scheme is not good enough to meet the needs of enterprises. Based on the concept of "post ability, teacher first”, the research was initiated in 2010 to form a spiral-upgrading teacher's ability upgrading plan and put it into practice.

The contents of the achievements are as follows: (1) It has completed the spiral-upgrading teacher's ability upgrading plan in the civil engineering of higher vocational colleges in China. The investigation report of teacher's ability promotion and the related data analysis work are completed. (2) We took the lead in completing the development of Shandong Province's engineering cost professional teaching guidance program, and participated the completion of in other professional teaching guidance program development work, such as the construction engineering technology and construction project management. 3We have developed and implemented the provincial summer teacher training for engineering cost in Shandong Province many times. (4)We have established high quality resource sharing courses based on information technology such as BIM; 5In order to adapt to the new needs of the construction industry upgrading, the teaching and scientific research projects which under the background of information BIM technology, assembly construction and green building, have been carried out.

The results are embodied in the following aspects: (1) Student's skills competition has improved; (2) Students' practical innovation ability has been improved; (3) The teachers' informatization teaching ability improves; (4)Teachers' ability to develop curriculum resources has been improved; (5)The students' post ability is well connected with the needs of the enterprises; 6) We have built a provincial excellent teaching team.

After 4 years of teaching practice, the research group published 5 pieces of paper, one of which was included in EI. Students won 5 awards in skill competitions. We have completed two provincial high-quality resource libraries and one school-level high-quality resource library. We also got 11 awards for the projects. It has played a good driving role in improving the teaching ability of civil engineering teachers in higher vocational colleges both inside and outside the province.

\section{Summary}

With the rapid development of information technology, the degree of informatization in the construction industry has also been greatly improved. Civil engineering teachers must bravely face the requirements of new developments, closely follow the pace of BIM technology, assembly technology and green smart buildings brought about by the upgrading of the construction industry. Teachers must renew their knowledge, enhance practical operation skills, keep pace with technological upgrading, achieve match between vocational education and industrial development, and improve teachers' ability. At the same time, teachers should impart the forefront of new 
knowledge and new skills to students, so that students will be able to better adapt to the job needs in the future. In short, we must keep pace with the times, improve the quality of teaching, and cultivate qualified new-age talents.

\section{Acknowledgements :}

Research on the innovation of modern apprenticeship training mode for construction majors in higher vocational colleges (ZC15074)

\section{References}

[1] Yingxia Li, Xiuyun Guo, Guoming Li. Research on Professional Teachers' Engineering Practice Ability Cultivation: Taking Hebei Construction Engineering School as an Example [J].Wisdom, 2014(5)

[2] Wenying Dai. Research on Assembled Buildings Based on BIM Technology--Taking "Pomegranate House" as an Example[D]. Wuhan University. 2017

[3] Mingtu Zhang. Application of BIM technology in civil engineering[D]. Hubei University of Technology, 2017(5)

[4] Cheng Li. BIM technology leads the transformation and upgrading of the building industry [J]. China Construction, 2017(5)

[5] Peidong Sang, Zhang Hao. The development trend and countermeasures of the modernization of construction industry under the “Internet+" era [J]. Journal of Engineering Management, 2017 (4)

[6] Yuanyuan Sun. Research on BIM technology planning system under the background of building industrialization[D]. Journal of Engineering Management, 2017(4) 